\title{
FURNITURE SKILLS TRAINING FOR PRISONER IN CLASS IIA PRISON
}

\author{
PELATIHAN KETERAMPILAN \\ FURNITURE BAGI WARGA BINAAN \\ PEMASYARAKATAN DI LAPAS KELAS \\ IIA
}

\author{
Sofyan Syahputra ${ }^{1}$ \\ ${ }^{1}$ Universitas Singaperbangsa Karawang \\ 22sofyansyahputra28@gmail.com
}

\begin{abstract}
This research is motivated by how the Furniture Skills Training Activities organized by the Karawang Class IIA prison take place. This furniture skills training activity is a part of the coaching program at the institute. With the aim that the fostered citizens are more skilled and more formed daily character both in the prison environment and when later after being free of sentence. This research approach used is qualitative research with descriptive research type. With the subject of research 1 prison officer, 1 instructor and 2 prisoners who participated in furniture skills training activities. The instrument used is Observation, Interview and documentation so that the expected data can be obtained optimally. The results obtained in this study are: 1) knowing the process of furniture skills training held by class IIA prison in Karawang . 2) find out the inhibiting factors for furniture skills training for prisoners in class IIA prison in Karawang. 3) find out the results achieved for prisoners in class IIA prison in Karawang
\end{abstract}

Keywords: fostering skills in prisons, furniture training in prisons

\begin{abstract}
ABSTRAK
Penelitian ini dilatarbelakangi oleh bagaimana Kegiatan Pelatihan Keterampilan Mebel yang diselenggarakan oleh Lapas Kelas IIA Karawang berlangsung. Kegiatan pelatihan keterampilan mebel ini merupakan bagian dari program pembinaan di institut. Dengan tujuan agar warga binaan lebih terampil dan lebih terbentuk karakter sehari-hari baik di lingkungan penjara maupun saat nanti setelah bebas dari hukuman. Pendekatan penelitian yang digunakan adalah penelitian kualitatif dengan jenis penelitian deskriptif. Dengan subjek penelitian 1 petugas lapas, 1 instruktur dan 2 narapidana yang mengikuti kegiatan pelatihan keterampilan mebel. Instrumen yang digunakan adalah Observasi, Wawancara dan dokumentasi sehingga data yang diharapkan dapat diperoleh secara optimal. Hasil yang diperoleh dalam penelitian ini adalah: 1) mengetahui proses pelatihan keterampilan mebel yang diselenggarakan oleh Lapas kelas IIA Karawang. 2) mengetahui faktor penghambat pelatihan keterampilan meubel bagi narapidana di Lapas kelas IIA Karawang. 3) mengetahui hasil yang dicapai narapidana di Lapas kelas IIA Karawang.
\end{abstract}

Kata Kunci: pembinaan keterampilan di lapas, pelatihan mebel di lapas 


\section{PENDAHULUAN}

Lembaga pemasyarakatan pada hakekatnya merupakan muara akhir dari sistem pemidanaan kejahatan dalam system peradilan pidana di Indonesia. Lembaga Pemasyarakatan (disingkat Lapas) adalah tempat untuk melakukan pembinaan terhadap narapidana dan anak didik pemasyarakatan di Indonesia. Sebelum dikenal istilah lapas di Indonesia, tempat tersebut disebut dengan istilah penjara (Wulandari, 2012).

Lembaga Pemasyarakatan merupakan Unit Pelaksana Teknis di bawah Direktorat Jenderal Pemasyarakatan Kementerian Hukum dan Hak Asasi Manusia (dahulu Departemen Kehakiman). Penghuni Lembaga Pemasyarakatan bisa narapidana (napi) atau Warga Binaan Pemasyarakatan (WBP) bisa juga yang statusnya masih tahanan, maksudnya orang tersebut masih berada dalam proses peradilan dan belum ditentukan bersalah atau tidak oleh hakim. Pegawai negeri sipil yang menangani pembinaan narapidana dan tahanan di lembaga pemasyarakatan disebut Petugas Pemasyarakatan, atau dahulu lebih dikenal dengan istilah sipir penjara (Hamja, 2016).

Konsep pemasyarakatan pertama kali digagas oleh Menteri Kehakiman Sahardjo pada tahun 1962. Ia menyatakan bahwa tugas jawatan kepenjaraan bukan hanya melaksanakan hukuman, melainkan juga tugas yang jauh lebih berat adalah mengembalikan orang-orang yang dijatuhi pidana ke dalam masyarakat. Pada tahun 2005, jumlah penghuni Lapas di Indonesia mencapai 97.671 orang, lebih besar dari kapasitas hunian yang hanya untuk 68.141 orang. Maraknya peredaran narkoba di Indonesia juga salah satu penyebab terjadinya kelebihan kapasitas pada tingkat hunian Lapas.

Lembaga pemasyarakatan yang diselenggarakan oleh pemerintah ditujukan untuk memberi wadah dan membina narapidana/warga binaan agar mereka mempunyai cukup bekal guna menyongsong kehidupan setelah selesai menjalani masa pidana. sebagaimana tercantum pada pasal 2 undang-undang no.12 tahun 1995 tentang pemasyarakatan,bahwasannya system pemasyarakatan diselenggarakan dalam rangka agar membentuk warga binaan seutuhnya menyadari kesalahan, meperbaiki diri,dan tidak mengulangi lagi tindak pidana sehingga dapat diterima kembali di lingkungan masyarakat, dan dapat aktif berperan dalam pembangunan dan dapat hidup sebagai warga yang baik dan bertanggung jawab, dengan di terapkannya system pemasyarakatan ini narapidana diharapkan telah siap untuk dapat berinteraksi secara social di dalam masyarakat setelah melalui tahap pembinaan, di dalam lembaga pemasyarakatan ada berbagai macam pembinaan di dalam lapas sebagai salah satunya yaitu pembinaan pelatihan keterampilan furniture yang dimaksudkan untuk meningkatkan keterampilan para warga binaan yang ada di dalam lapas tersebut (Almareza, 2016).

Tujuan dari pembinaan yang di lakukan lembaga pemasyarakatan tidak lain agar warga binaan tidak lagi mengulangi perbuatannya dan bisa kembali menemukan kepercayaan dirinya serta dapat diterima menjadi bagian dari anggotan masyarakat (Khotimah, 2016; Nazifah, 2015). Asimilasi adalah tahapan tahapan pembinaan terhadap warga binaan yang telah menjalani $1 / 2$ (setengah) masa pidana nya.lembaga pemasyarakatan terbuka sebagi salah satu unit pelaksanaan teknis pada kementrian hukum dan hak asasi manusia yang di bentuk untuk melaksanakan asimilasi terhdap warga binaan, memiliki peran penting dalam pembinaan kepribadian dan kemandirian sehingga warga binaan benar-benar siap berinteraksi secara sosial dan kembali menjalani kehidupan bermasyarakat yang baik. lembaga pemasyarakatan kelas IIA karawang merupakan salah satu lapas yang ada di Indonesia yang telah di bentuk oleh direktorat jenderal pemasyarakatan kementrian hukum dan hak asasi manusia. 


\section{METODE}

Penelitian ini menggunakan pendekatan penelitian kualitatif, penggunaan penelitian kualitatif ini di gunakan untuk menggambarkan dan mengamati keadaan proses dari awal sampai akhir.sedangkan metode yang digunakan adalah studi kasus, metode studi kasus ini digunakan untuk mengungkapkan kenyataan yang ada atau yang terjadi di lapangan untuk di pahami secara mendalam, sehingga pada akhirnya diperoleh temuan data yang diperlukan sesuai dengan tujuan penelitian (Moleong, 2017).

Subjek penelitian dalam penelitian ini adalah orang yang terlibat dalam pelaksanaan kegiatan pelatihan keterampilan furniture di lapas kelas IIA karawang yang meliputi: (1) kepala seksi kegiatan kerja (2) istruktur pelatihan (3) wargabinaan pemasyarakatan yang menjadi peserta pelatihan.

Teknik pengumpulan data yang digunakan antara lain: (1)observasi (2)wawancara dan (3)dokumentasi .sedangkan untuk teknik analisi data yang digunakan antara lain: (1) koleksi data (2) reduksi data (3) display data (4) verifikasi dan kesimpulan.

\section{PEMBAHASAN}

Penentuan subjek penelitian pelatihan keterampilan furniture di lapas kelas IIA karawanag berdasarkan hasil observasi,wawancara,dan dokumentasi dengan kepala seksi kegiatan kerja,instruktur pelatihan furniture,dan warga binaan pemasyarakatan yang mengikuti pelatihan, Menurut Edwin B. Flippo, sebagaimana yang dikutip oleh Kamil (2012), mengungkapkan bahwa pelatihan yaitu "Training is the act of increasing the knowledge and skill, of an employee for doing a particular job" (pelatihan adalah tindakan meningkatkan pengetahuan dan keterampilan seorang pegawai untuk melaksanakan pekerjaan tertentu),maka berdasarkan ke tiga jenis sample data tersebut maka diperoleh data-data yaitu sebagai berikut:

\section{Proses pelatihan keterampilan furniture bagi warga binaan pemasyarakatan di lapas kelas IIA karawang}

Berdasarkan data yang diperoleh yaitu pada proses pelatihan keterampilan furniture bertujuan agar warga binaan pemasyarakatan memiliki bekal keterampilan sehingga setelah mereka selesai menjalani masa pidana warga binaan pemasyarakatan dapat hidup mandiri dilingkungan masyarakat pelatihan keterampilan furniture sendiri adalah salah satu bentuk pelatihan yang di laksanakan oleh Lembaga Pemasyarakatan Kelas IIA Karawang sebagai upaya pembinaan agar para warga binaan mampu beradaptasi secara baik di masyarakat setelah mereka bebas nanti.

latar belakang diselenggarakannya pelatihan keterampilan furniture di lembaga pemasyarakatan kelas IIA karawang ini didasarkan pada keinginan dan kebutuhan wargabinaan pemasyarakatan. sementara lembaga hanya mefasilitasi minat dan bakat dari wargabinaan tersebut apabila ada wargabinaan pemasyaraktan yang memiliki minat dalam pelatihan yang terdapat di lapas mereka dapat mengikutinya asalkan mereka memiliki ketertarikan dan minat pada pelatihan yang ada,sedangkan jika ada pelatihan yang mereka minati tetapi tidak terdapat di lapas maka wargabinaan bias mengajukan kepada pihak lapas dan pihak lapas akan memfasilitasi pelatihan tersebut dengan syarat peserta pelatihan harus mencapai 6 sampai 10 peminat yang mengikutinya. 
Selama proses kegiatan pelatihan keterampilan furniture instruktur menggunakan metode praktek dan Tanya jawab dalam melatih peserta pelatihan atau warga binaan pemasyarakatan di lapas kelas IIA karawang, penggunaan metode tersebut dilakukan dikarenakan warga binaan lebih mudah mengerti penjelasan instruktur secara langsung atau melihat secara langsung cara-cara pembuatan furniture dan apabila mengalami kesulitan atau ada yang tidak dimengerti mereka dapat bertanya pada instruktur dan selanjutnya instruktur akan menjelaskan pada warga binaan pemasyarakatan sampai benar-benar paham.

Kegiatan proses pelatihan keterampilan furniture sendiri dilakukan setiap hari kerja yaitu senin sampai jumat yang bertempat di ruangan khusus untuk melakukan kegitan pelatihan keterampilan, adapun alat-alat yang digunakan dalam kegiatan pelatihan antara lain: mesin bor, jigsaw, meja gergaji, mesin pasah, spray gun, trimmer mesin, kompresor dan,lain,sebagainya.

\section{Faktor penghambat pelatihan keterampilan furniture bagi warga binaan pemasyarakatan di lapas kelas IIA karawang}

Dalam pelaksanaan pelatihan keterampilan furniture di Lembaga Pemasyarakatan Klas IIA karawang terdapat faktor penghambat atau kendala. Faktor-faktor tersebut sangat berpengaruh terhadap berlangsungnya pelaksanaan pelatihan keterampilan furniture. Faktor penghambat atau kendala dalam pelaksanaan pelatihan keterampilan furniture tersebut yaitu para warga binaan yang mengikuti pelatihan keterampilan furniture pada umumnya mempunyai sikap yang keras dan kurang disiplin sehingga dalam pelaksanan pelatihan keterampilan yang sedang berlangsung sering terjadi perselisihan antar warga binaan, dan keterlambatan didalam kegiatan pelatihan, disinilah peran instruktur untuk bersikap tegas dengan melerai dan mengingatkan pada warga binaan pemasyarakatan tersebut.

Untuk sarana prasarana sendiri bisa dibilang masih cukup terbatas seperti alat-alat yang digunakan dalam pembuatan furniture yang masih terbatas sehingga warga binaan pemasyarakatan harus bergantian dalam menggunakannya, tetapi hal itu tidak menjadi halangan dalam kegiatan pelatihan keterampilan di lapas kelas IIA karawang.

\section{Ketercapaian hasil pelatihan keterampilan furniture bagi warga binaan pemasyarakatan di lapas kelas IIA karawang}

Dalam setiap kegiatan pelatihan sendiri pasti diinginkan ketercapaian atau hasil yang didapat begitu juga dalam kegiatan pelatihan keterampilan furniture di lapas kelas IIA karawang ini antara lain,pada awalnya warga binaan pemasyarakatan memiliki sikap yang keras dan tidak disiplin tetapi perlahan seiring berjalannya proses kegiatan pelatihan dengan dibimbing dan diarahkan sikap yang mereka miliki berubah menjadi lebih baik.

Selain itu warga binaan pemasyarakatan dapat memiliki keterampilan dalam menggunakan alat-alat dalam pembuatan furniture seperti mesin bor,jigsaw, meja gergaji,mesin pasah,spray gun,trimmer mesin,kompresor dan lain sebagainya, mereka juga dapat membuat produk furniture buatan mereka sendiri seperti meja, lemari dan lain sebagainya.

\section{KESIMPULAN}

Berdasarkan hasil penelitian dan pembahasan mengenai pelatihan keterampilan furniture bagi warga binaan pemasyarakatan di lapas kelas IIA karawang maka dapat ditarik kesimpulan yaitu: (1) proses pelatihan keterampilan furniture yang dilaksanakan di lapas kelas 
IIA karawang sudah dilakukan sesuai dengan fungsinya.seperti metode praktek dan Tanya jawab dapat diterapkan dengan baik, untuk sarana dan prasarananya sudah cukup memadai meskipun masih serba keterbatasan;(2) faktor penghambat pelatihan keterampilan furniture sendiri yaitu sikap keras dan tidak disiplin yang dimiliki oleh warga binaan pemasyarakatan menjadi kendala tersendiri didalam kegiatan pelatihan, selain itu sarana dan prasarana yang ada masih cukup terbatas seperti alat-alat yang digunakan dalam pelatihan yang terbatas sehingga warga binaan pemasyarakatan harus bergantian dalam menggunakannya ;(3) ketercapaian hasil pada pelatihan keterampilan furniture ini yaitu warga binaan pemasyarakatan dapat memiliki keterampilan dibidang furniture seperti bisa menggunakan alat-alat untuk pembuatan furniture contohnya gergaji,spray gun dan lain sebagainya .merubah sikap warga binaan yang tadinya keras dan tidak disiplin menjadi lebih baik, dan juga merka berhasil membuat produk furniture buatan mereka sendiri yang tidak kalah bagus dari produk furniture diluaran sana.

\section{DAFTRA RUJUKAN}

Almareza, S. (2016). Perencanaan Pelatihan Keterampilan Kecakapan Hidup di Desa Vokasi Candi Kecamatan Bandungan Kabupaten Semarang [Universitas Negeri Semarang]. https://lib.unnes.ac.id/24076/

Hamja, H. (2016). Model Pembinaan Narapidana Berbasis Masyarakat (Community Based Corrections) dalam Sistem Peradilan Pidana. Mimbar Hukum - Fakultas Hukum Universitas Gadjah Mada, 27(3), 445. https://doi.org/10.22146/jmh.15882

Kamil, M. (2012). Model Pendidikan dan Pelatihan (Konsep dan Aplikasi). Alfabeta.

Kamil, Mustofa, (2009), Pendidikan Nonformal. Bandung : Alfabeta

Khotimah, K. (2016). Proses Pembinaan Warga Binaan Pemasyarakatan di Lembaga Pemasyarakatan Kelas IIA Wirogunan Yogyakarta. Universitas Negeri Yogyakarta.

Moleong, L. J. (2017). Metodologi Penelitian Kualitatif. PT Remaja Rosdakarya.

Nazifah, I. A. (2015). Penyelenggaraan Pembinaan Narapidana Bidang Kerajinan Tangan di Lembaga Pemasyarakatan Klas IIA Wanita Semarang. Universitas Negeri Semarang.

Pemerintah Indonesia. 1995.Undang - Undang nomor 12 tahun 1995 tentang Pemasyarakatan.

Trisnamansyah, S. 2005. Konsep Konsep Dasar Pendidikan Luar Sekolah, Program Studi Pendidikan Luar Sekolah, Program Pascasarjana, Universitas Islam Nusantara, Bandung.

Turere, V. N. (2013). Pengaruh Pendidikan Dan Pelatihan Terhadap Peningkatan Kinerja Karyawan Pada Balai Latihan Teknis Pertanian Kalasey. Jurnal Riset Ekonomi, Manajemen, Bisnis dan Akutansi, 1(3), 10-19

Wulandari, S. (2012). Efektivitas Sistem Pembinaan Narapidana di Lembaga Pemasyarakatan terhadap Tujuan Pemidanaan. Jurnal Hukum Dan Dinamika Masyarakat, 9(2), 131142. 